\title{
Black rice as a functional food in Indonesia
}

\author{
Rarastoeti Pratiwi $^{{ }^{*}}$ and Yekti Asih Purwestri ${ }^{1,2}$
}

${ }^{1}$ Laboratory of Biochemistry, Faculty of Biology, Universitas Gadjah Mada, Jl. Teknika Selatan, Sekip Utara, Yogyakarta, 55281, Indonesia; ${ }^{2}$ Research Center for Biotechnology, Universitas Gadjah Mada Jl. Teknika Utara, Barek, Sleman, Yogyakarta, 55281, Indonesia

*Corresponding author: Rarastoeti Pratiwi, M.Sc., PhD, Faculty of Biology, Universitas Gadjah Mada, Jl. Teknika Selatan Sekip Utara, 55281 Yogyakarta, Indonesia

Submission Date: October $7^{\text {th }}, 2016$, Acceptance date: March $24^{\text {th }}, 2017$, Publication date: March $31^{\text {st }}, 2017$

Citation: Pratiwi R., Purwestri Y.A. Black rice as a functional food in Indonesia. Functional Foods in Health and Disease 2017; 7(3): 182-194

\begin{abstract}
There are many local black rice cultivars in Indonesia, yet only a few of these are formally described in the literature. It has been reported that black rice has many phytochemical variants which may contribute to its use as a functional food, including nutraceuticals and secondary metabolites such as anthocyanin, oryzanol, and more. The purpose of this article was to review literature describing black rice cultivars from Indonesia, with a particular focus on its potential use as a functional food. Our literature search revealed several articles that describe black rice in relation to its nutraceutical properties and its role in reducing non-communicable diseases. Other studies describe the diversity of local pigmented rice and its potential for lowering the risk of hyperlipidemia, hyperglycemia, and for cancer prevention. Black rice has been described as a functional food in several countries; however, there is great diversity among cultivars and further research on Indonesian varieties will determine whether local variants are candidates as well for the development of functional foods.
\end{abstract}

Keywords: black rice cultivar, functional food, non-communicable diseases, nutraceutical, phytochemical

\section{INTRODUCTION}

Black (purple) rice is becoming popular not only for the development of functional foods, but also due to the genetic variability of cultivars which causes diversity in pigmentation, nutrition value, and phytochemical properties. Black rice belongs to Oryza sativa L., the same species as white rice and red rice. In Indonesia, Oryza sativa L. is divided into two subspecies, indica (non-sticky and long grain) and tropical japonica/javanica (sticky and short grain). However, phenotypic differences arise from the differential pigmentation of the aleuronic layer and other morphological characters, leading to black rice varieties within these subspecies. These differences may account 
for its effects on human health. Indonesian folklore ascribes many health-related benefits to black rice $[1,2,3]$. With regard to black rice, black glutinous/waxy/sticky rice is more popular than nonsticky and long grain black rice. Most studies suggest that black rice contains a variety of bioactive compounds, predominately anthocyanin. However, black rice is still less popular than white rice and red rice as a staple food. There are few publications regarding black rice research in Indonesia, especially as related to the development of black rice as a functional food. On the other hand, many studies in the literature describe black rice that originates from Korea, India, Japan, Thailand, European countries, and the United States of America. This review will evaluate the literature on Indonesian black rice cultivars and will thereby narrow an existing information gap in black rice research.

\section{Black Rice Varieties}

\section{Varieties around the world}

Indonesia was one of the first places to first domesticate and then cultivate rice, with other varieties arising independently in China and India. There are three varietal groups of rices that were predominantly cultivated in Asia, including japonica, indica, and javanica [4]. Black rice is a pigmented rice which is planted across a wide area in Asia, an area which includes India, Bangladesh, China, Korea, Japan, Thailand, Laos, Vietnam, and Indonesia. However, the history of black rice domestication remains unclear. In some historical accounts, black rice was also called "forbidden rice" in texts dating back to China's imperial age [5].

Black rice pigmentation has a broad spectrum of seed colors that depend on many factors. The wide geographic distribution of black rice across both lowlands and highlands in Asia has led to environmental adaptations which lead to diversity among varieties and give each cultivar different morphological characteristics and phytochemical properties [6, 7, 8, 9]. A recent study reported that pigmentation in black rice results from the activity of the Kala4 gene, which is necessary for anthocyanin synthesis. This same study suggested that there were mutations in the promoter of Kala4 which give rise to the black rice phenotype. This mutation arose in tropical japonica and then spread to the indica subspecies subsequently [10].

More than 200 types of black rice varieties are found around the world. Most agricultural black rice is planted in China, followed by Sri Lanka, Indonesia, and India, and these varieties are identified by accession numbers the germplasm collection of 359, 50, 42, and 30 respectively. However, some types grow in several countries, including the Philippines, Bangladesh, Korea, and Japan [11]. Previous studies on colored rice varieties from Thailand, China, and Sri Lanka suggest that there is a phytochemical spectrum that overlaps between red and black rice which corresponds to a smooth distribution of color phenotypes that span these groups. Anthocyanin is the dominant colored compound in black rice. For example, the magnitude of anthocyanin content may contribute to both the color and the antioxidant activity found in each cultivar $[12,13,14]$. Therefore, variations in type group (varieties), color, anthocyanin, and other metabolites may have implications in understanding various black rice phenotypes and their potential uses as a functional food.

\section{Varieties in Indonesia}

In Indonesia, there are many kinds of local black rice varieties planted across the country. The various names of cultivars are region-specific and often refer to the region where the cultivar originates (Table 1). As of 2015, surveys of black rice varieties in Indonesia revealed that there 
are six varieties from Central Java, five varieties from Yogyakarta, four varieties from Nusa Tenggara Timur, six varieties from Sulawesi Island, and one variety each from Kalimantan (Borneo) and West Java. It is possible that many more varieties exist. For example, in Yogyakarta (Java), black rice is known by more than five names; these names reflect people and/or the geographic location, village, or the name of the original rice plantation where the strain originated. The five names for 'Padi Hitam' or black rice are Ngadiman, Pakem; Yuniarto, Bantul; Didi, Pakem; Gunarto, Pakem; and Sangidu, Bantul. However, it is still unknown whether these are the same or different cultivars [15].

Several Indonesian black rice types have been categorized into different groups based on morphological characteristics and genetic variability [3]. Furthermore, studies suggest that a single group may exhibit a high degree of variability with regard to color and total anthocyanin content that indicate broad genetic variability. There are color variations among black rice cultivars, and anthocyanin content was discovered to be negatively correlated with darker varieties of black rice [16]. A recent study reported that thirteen pigmented waxy and non-waxy rice varieties (including two non-waxy black rice, Ambo Tanduk and Ambo Awok) were planted in three climatic zones of South Sulawesi. They differ not only in grain dimension, color, and proximate composition, but also in phenolic and anthocyanin contents [17].

Indonesia has 50 accession numbers for germplasm collections [11]. However, according to recent reports, Indonesian researchers reported only 24 names of local black rice cultivars $[3,15$, $17,18,19]$. This suggests that black rice cultivars corresponding to these accession numbers need to be further analyzed for their genotypes. One possible method for doing so is high throughput SNP genotyping, which has been shown to be a reliable technique for characterizing rice germplasm in Indonesia [20]. Therefore, an intensive study on genetic variability of Indonesian black rice would be beneficial for improving selective breeding based on the morphological, phytochemical, and molecular characterization of rice genotypes.

\section{Black Rice and Health Antioxidant activity}

Many studies suggest that black rice bran has strongly antioxidant activities due to phenolic and anthocyanin-rich flavonoids [21, 22, 23]. A review [24] which summarized 316 rice-focused publications demonstrated that phenolic acids, flavonoids, anthocyanins, proanthocyanidins, tocopherols, tocotrienols, c-oryzanol, and phytic acid are the major antioxidant components in 4 rice types, which may also contribute to differences in color (white, brown, red and black). This review also suggested that japonica and indica rice varieties differ in the antioxidants they contain, with japonica having a higher concentration of antioxidants than in indica. Another study [25] suggested that ferulic acid is a dominant compound in black rice bran which contributes to its antioxidant activity. This contrasts with another report that indicated [26] ferulic acid is a good antioxidant in white rice but less in black rice bran extract. However, most studies report that anthocyanin is the dominant compound in black rice bran, suggesting that cyanidin and peonidin are additional potential antioxidant compounds for food additive materials [21, 22, 26, 27, 28]. 
Table 1. Black rice varieties names from several regions in Java and other islands in Indonesia

\begin{tabular}{|c|c|c|c|c|c|}
\hline No. & Name of rice & Region & Province & Island/Island ${ }^{\wedge}$ & Ref/web \\
\hline 1. & Melik & Ganjuran - Bantul & Yogyakarta & Java & 16 \\
\hline 2. & Jlitheng & Sleman & Yogyakarta & Java & 16 \\
\hline 3. & Cempo Ireng & Seyegan - Sleman & Yogyakarta & Java & 16 \\
\hline 4. & Pari Ireng & $\begin{array}{l}\text { Padasan - Pakmbinangun } \\
\text { - Sleman }\end{array}$ & Yogyakarta & Java & 3 \\
\hline 5. & $\begin{array}{l}\text { Padi Hitam } \\
\text { Bantul }\end{array}$ & Njayan - Imogiri - Bantul & Yogyakarta & Java & 3 \\
\hline 6. & $\begin{array}{l}\text { Padi Hitam } \\
\text { Magelang (Hairy) }\end{array}$ & Sawangan - Magelang & Central Java & Java & 3 \\
\hline 7. & $\begin{array}{l}\text { Padi Hitam } \\
\text { Magelang } \\
\text { (hairless) }\end{array}$ & Sawangan - Magelang & Central Java & Java & 3 \\
\hline 8. & Wulung & Surakarta & Central Java & Java & 3 \\
\hline 9. & $\begin{array}{l}\text { Padi Hitam } \\
\text { Wonosobo }\end{array}$ & Wonosobo & Central Java & Java & 3 \\
\hline 10. & $\begin{array}{l}\text { Padi Hitam } \\
\text { Sragen }\end{array}$ & Sragen & Central Java & Java & 3 \\
\hline 11. & $\begin{array}{l}\text { Padi Hitam } \\
\text { Banjarnegara }\end{array}$ & Banjarnegara & Central Java & Java & 3 \\
\hline 12. & $\begin{array}{l}\text { Beras Hitam } \\
\text { Sirampog }\end{array}$ & Brebes & Central Java & Java & $*$ \\
\hline 13. & $\begin{array}{l}\text { Beras hitam } \\
\text { cibeusi/ Gadong }\end{array}$ & Cibeusi-Subang & West Java & Java & 19 \\
\hline 14. & Laka & Manggarai & $\begin{array}{l}\text { East Nusa } \\
\text { Tenggara }\end{array}$ & $\begin{array}{c}\text { Nusa } \\
\text { Tenggara }\end{array}$ & 18 \\
\hline 15. & Woja Laka & Manggarai & $\begin{array}{l}\text { East Nusa } \\
\text { Tenggara }\end{array}$ & $\begin{array}{c}\text { Nusa } \\
\text { Tenggara }\end{array}$ & 18 \\
\hline 16. & Aen Meta & Alor & $\begin{array}{l}\text { East Nusa } \\
\text { Tenggara }\end{array}$ & $\begin{array}{c}\text { Nusa } \\
\text { Tenggara }\end{array}$ & 19 \\
\hline 17. & Hare Kwa & Alor & $\begin{array}{l}\text { East Nusa } \\
\text { Tenggara }\end{array}$ & $\begin{array}{c}\text { Nusa } \\
\text { Tenggara }\end{array}$ & 19 \\
\hline 18. & $\begin{array}{l}\text { Pae Biyu } \\
\text { Nggolopua }\end{array}$ & Kendari & $\begin{array}{l}\text { Souh East } \\
\text { Sulawesi }\end{array}$ & Sulawesi & 19 \\
\hline 19. & $\begin{array}{l}\text { Pare Durian- } \\
\text { ujung }\end{array}$ & Tana Toraja & South Sulawesi & Sulawesi & $* *$ \\
\hline 20 & $\begin{array}{l}\text { Pare Puluk } \\
\text { lontong }\end{array}$ & Gowa & South Sulawesi & Sulawesi & 19 \\
\hline 21. & Rentepau & Tana Toraja & South Sulawesi & Sulawesi & 19 \\
\hline 22 & Ambo Tanduk & Tana Toraja & South Sulawesi & Sulawesi & 17 \\
\hline 23 & Ambo Awok & Tana Toraja & South Sulawesi & Sulawesi & 17 \\
\hline 24. & Pulut Hitam & Dayak & $\begin{array}{l}\text { Central } \\
\text { Kalimantan }\end{array}$ & Kalimantan & 19 \\
\hline
\end{tabular}

*http://brebesnews.co/2014/03/dinas-pertanian-bidang-agribisnis-luncurkan-jah-saritem-asli-sirampog/\#.VJuNsDAJ0

**http://bp3kbamburuncingparakan.blogspot.com/2010/07/beras-hitamblack-riceberas-ireng.html 
Black rice cultivars are significantly variable in their secondary metabolite composition, especially anthocyanin [22, 29]. Accordingly, some varieties are better candidates as a source of antioxidants than others [30]. Anthocyanin compounds in black rice include cyanidin 3-Oglucoside, peonidin 3-O-glucoside, malvidin 3-O-glucoside, pelargonidin 3-O-glucoside, and delphinidin 3-O-glucoside [28]. However, the most abundant anthocyanin in black rice bran is cyanidin-3-O-glucoside ( 95\%) followed by peonidin-3-O-glucoside concentrations of less than $5 \%$ [21]. It has also been reported that the phenolic compound abundant in black rice bran extract were hydroxycinnamic acids (especially, ferulic acid [4-hydroxy-3-methoxy-cinnamic acid). The concentrations of hydroxycinnamic acids have also been reported to correlate with the antioxidant activity of black rice bran extract [25].

An Indonesian study about black rice and the activities of its antioxidant compounds [3] reported that there is significant variation in total anthocyanin contents among 11 black rice cultivars (mostly from Java). These ranged from 53.22 to $650.37 \mathrm{mg} / 100 \mathrm{~g}$ black rice bran. These anthocyanin concentrations are higher than total anthocyanin from another report, which examined 22 highland pigmented rice cultivars from Southeast Sulawesi. In these cultivars, anthocyanin ranged from 0.03 to $210.51 \mathrm{mg} / 100 \mathrm{~g}$ rice bran extract (mostly red rice). However, there is no information on the antioxidant activity. Another study [30] reported about phenolic, flavonoid, alkaloid, triterpenoid, and saponin compounds in the crude extract of colored and non-colored rice from Minahasa, North Sulawesi. Their work suggested that crude extract of colored rice bran is potentially a better natural antioxidant source compared to non-colored rice. Further, this study reported that anthocyanin and phenolic contents of waxy black rice are higher than non-waxy black rice (varieties from South Sulawesi) and that the antioxidant activity was positively correlated with total phenolic and anthocyanin compounds. They suggested that waxy black rice is more potent than non-waxy black rice in nutraceutical product formulation. In summary, the antioxidant compounds and antioxidant activity differs among varieties of black rice cultivars. Therefore, it is important to define which cultivars have the potential to be developed for use as functional foods in Indonesia.

\section{Antihyperlipidemia and antihyperglycemia}

In recent decades, diseases associated with the conditions of hyperlipidemia and hyperglycemia, including cardiovascular disease and diabetes, have been increasing significantly. Anthocyaninrich in plant food may have therapeutic uses in the treatment of cardiovascular diseases by enhancing cellular cholesterol removal via apolipoproteins [31]. Many studies report that the incorporation of colored rice into diets could be beneficial due to the anthocyanin and other active compounds that are components of rice bran extract. The most abundant anthocyanin in black rice bran extract is cyanidin 3-glucoside, which has hypolipidemia effects via regulating hepatic lipogenic enzyme activities [32]. Additionally, anthocyanin-rich extract from black rice has been shown to prevent hyperlipidemia and diabetic syndromes in fructose-fed rats [33].

Besides anthocyanin, colored rice contains lipid components such as triacylglycerol, free fatty acids, phospholipids, and other less prevalent lipid-based compounds. All kinds of colored rice have similar lipid constitutions with little variation [34]. For example, previous studies have suggested that colored rice has antiatherogenic potential in hypercholesterolemic rabbits [35] and rats [36]. One study [31] reported that black rice pigment is responsible for the inhibition of atherosclerotic lesions via a reduction in oxidative stress and inflammation. Dietary supplements containing black rice extract could normalize serum lipid profiles and induce the expression of genes involved in fatty acid metabolism [37]. 
Black rice bran is rich in anthocyanin, a hydrophilic compound, in addition to tocols lipids. A study reported that anthocyanin extract from black rice is better able to emulsify cholesterol than tocols. The same study suggested that tocols are better inhibitors of fatty acid oxidation than anthocyanin [38]. Furthermore, a recent study suggested that black rice extract has the potential to inhibit adipogenesis by enhancing the expression of WnT3a and $\beta$-catecin. These genes are involved in signaling pathways which are responsible for switching between osteogenic and adipogenic cell differentiation [39].

A few research groups have carried out studies that seek to determine whether Indonesian black rice cultivars can be used to prevent diseases associated with hyperlipidemia and hyperglycemia. For instance, one study [40] suggested that a diet supplemented with a black rice called 'Cempo Ireng', a cultivar from Indonesia, improved the serum lipid profiles within hyperlipidemia rats better than red or white rice supplementation. A recent study suggested that the ethanolic extract of Indonesian cultivar black rice bran inhibited a-glucosidase activity and induced regeneration of pancreatic beta cells, thereby causing an increase of blood insulin level in alloxan-induced diabetic rats [41].

\section{Cancer prevention}

According to the American Cancer Society [42, 43], the definition of cancer is a group of diseases characterized by uncontrolled growth and spread of abnormal cells. If the spread of these cells is not controlled, it can result in death. Unfortunately, cancer is highly prevalent in the United States of America and other countries. For example, studies consistently demonstrate a significant number of increasing cases of cancer and similar statistics of cancer deaths each year. For example, some reports estimate that they were 1,660,290 and 1,685,210 of new cancer cases in 2013 and 2016 respectively, with 580,350 and 595,690 of cancer deaths in these same years.

Cancer can be treated with surgery, radiation, chemotherapy, hormone therapy, immune therapy, and targeted therapy. However, these treatments are painful and can sometimes cause severe side effects in cancer patients. Moreover, there is evidence that a healthy lifestyle, including a diet rich with natural products (fruits, vegetables, herbs, and cereals), can help reduce the risk of cancer [43]. Some of the phytochemicals in these natural products are secondary metabolites, including flavonoids, phenols, terpenoids, and alkaloids.

Flavonoids and phenols are the major compounds in rice (especially colored rice) bran that have been suggested to have anti-cancer properties for several types of cancer cells. Many studies have used in-vitro cancer cell models, including cell lines derived from breast, colon, cervix, leukemia, liver, and stomach, in order to evaluate the anti-cancer properties of compounds found in black rice [44, 45, 46, 47, 48, 49]. Some evidence indicates that flavonoids and phenolic compounds in black rice bran work via different mechanisms. The varieties of compounds in each black rice cultivars may influence the mechanism of inhibiting cancer cell growth in-vitro.

Cyanidin 3-glucoside and peonidin 3-glucoside from black rice anthocyanin can be combined with doxorubicin to inhibit cancer cell growth. It has been reported that these anthocyanins could be used for cancer chemoprevention. This research also suggests that both active anthocyanin compounds could inhibit the cancer invasion into other tissues. The invasion may occur through down regulation of the degradative enzymes MMP-2 and MP-9 [50]. Black rice ('Cempo Ireng') bran extract fractions, which contain cyanidin 3-glucoside and peonidin 3-glucoside, have cytotoxic activities and induce apoptosis of cervical cancer cells [51]. Most of the studies on cancer prevention by using black rice compounds remain in vitro approach; however, only a few publications applied in vivo (preclinical) and clinical approaches. Further research will be needed that investigates the anti-cancer effects of functional foods with human subjects. 


\section{Black Rice for Functional Foods}

Functional foods are defined as foods that promote health, not only by reducing the disease risk and slowing the aging process but also by enhancing the immune response. Functional foods should be consumed as part of a "normal' diet without consuming unusual quantities of a given food; in that way, functional foods differ from supplement tablets or traditional herbal medicine. This kind of food product could be obtained using procedures acceptable to the food industry to improve the quality of new products to meet the market demand [52]. Functional foods will need to be formulated to be healthy, but to also retain good taste and remain aesthetically pleasing to consumers.

Accordingly, the development of black rice as a functional food depends on producing enough rice to meet consumer demand. 'Cempo Ireng' is a local black rice that has been characterized genotypically and phenotypically [16]. However, this cultivar is not preferred by farmers due to the very long harvest period (5-6 months from transplanted seedling to harvest) and low yield. Thus, we should implement efforts to shorten this flowering period to enhance yield. To overcome this problem, a preliminary study has been initiated in order to investigate and understand flowering behaviour [53]. Recent studies suggest that 'Cempo Ireng' black rice grown under neutral day conditions has a flowering pathway conserved with a rice model grown under SD/LD condition. Preliminary results indicate that the flowering genes $H d 3 a$ and $R F T 1$ were expressed under neutral day conditions in tropical regions [54].

In Indonesia, information about black rice production is very limited. Not much research and data exists regarding black rice productivity. However, a report from the local entrepreneurship news website [55] also described how the production of black rice is about 3 tons per hectare and that the plants were harvested at 120-140 days compared to white rice, which only needs about 90 days of harvesting time to produce 6-7 tons per hectare. Consequently, the production yields for black rice may need to increase, while the harvesting time will certainly need to be shortened. Further work will be necessary regarding the period of growth and flowering before black rice can be developed into a functional food crop that will succeed in the marketplace.

Many publications report that black rice seed components including rice hulls, rice bran, and rice bran oils could be used for the development of functional foods [56]. Black rice contains nutrient-rich substances [57] and many kinds of bioactive compounds. These compounds include seven kinds of anthocyanin-rich in cyanidin-3-O-glucoside and peonidin-3-O-glucoside; 5 flavonol glycosides, especially quercetin-3-O-glucoside and quercetin-3-O-rutinoside; carotenoids i.e. lutein, zeaxanthin, lycopene, and b-carotene; c-oryzanol mixture with 24methylenecycloartenol ferulate, campesterol ferulate, cycloartenol ferulate and b-sitosterol ferulate [58]. Several studies suggest that black rice components play a role in the prevention of diseases such as inflammation, infections, diabetes, cardiovascular and cancer. Furthermore, black rice could be processed for the use of the production of bread, flakes, frankfurters, ice cream, noodles, pasta, tortillas, and zero-trans-fat shortening, which may make it more attractive for consumers [56].

In particular, anthocyanin from black rice is an excellent candidate for functional food development [59]. However, anthocyanin may be difficult to stabilize due to its chemical properties. Several studies have been initiated to enhance the stability of anthocyanin-glucoside during the processing of functional foods. For example, the addition of acid compounds to anthocyanin-rich fractions suggested that carboxylic acids [60] in addition to sinapic, ferulic, and p-coumaric acids [61] influence the color enhancement and stability of black rice juice during storage. However, the use of ascorbic acids could reduce anthocyanin stability and the same study suggests that when ascorbic acid is added during food processing, it would be better to encapsulate 
the ascorbic acids [62]. With other manufacturing processes, extraction by heating may reduce the total anthocyanin and phenolic contents and antioxidant activity in black rice; however, pregelatinized treatment enhances the antioxidant properties stability [12]. In Indonesia, research on functional food development has been initiated by using traditional colored rice cultivars ( 790 and Jowo). A study reports that black rice and red rice have a higher concentration of trace minerals (Fe and $\mathrm{Zn}$ ), carotenoid, vitamin E, anthocyanin, and phenolic contents than white rice. However, the boiling process may reduce these physicochemical properties [63]. Research into the degradation kinetics of anthocyanin during baking has demonstrated that cyanidin-3-glucoside is less thermally stable than cyanidin 3-rutinoside. Consequently, anthocyanin-rich black rice powder should be evaluated for development as a functional food [64]. Furthermore, a recent study reported that anthocyanin-rich black rice powder added to bread could improve the quality of bread properties and increase its digestibility [65]. Therefore, further research is required to understand the properties of black rice and its components, in addition to how these characteristics are maintained during processing, especially with regards to local Indonesian cultivars.

Nonetheless, there are several obstacles to the development of functional foods in Indonesia. Research in Indonesia is limited, especially compared to the research available in other countries including China, Korea, India, and Thailand (Table 2). Future efforts will select local cultivars of black rice based on their potential for nutritional value, health benefits, phytochemical properties, and appropriateness for large scale agricultural production.

Table 2. Publications related to the development of black rice as functional foods in Indonesia

\begin{tabular}{lll}
\hline Topics of Black Rice Studies & References \\
\hline Black Rice Plant & Variability of cultivars & $15,16,17,18,19$ \\
& Black rice plantation & 15,18 \\
& Long harvest period & 53,54 \\
& Productivity & 55 \\
& Phenotypic descriptions of black rice & 15 \\
& cultivars & \\
& Genetic and phenotypic correlation & 16 \\
& Genes involved in flowering & 53,54 \\
& Nutrient composition & 17,63 \\
& Secondary metabolites & $17,30,63$ \\
\hline Functional and & Antioxidant & 63 \\
bioactivities studies & Antihyperlipidemia & 40 \\
& Antihyperglicemia & 41 \\
& Cancer prevention & 51 \\
\hline Functional food & Whole grain & 63 \\
development & Rice bran & 30 \\
& Cookies prototype & Our research group \\
& & (unpublish report) \\
& Rice crunch/flake prototype & Our research group \\
& & (unpublish report) \\
\hline
\end{tabular}




\section{CONCLUSIONS}

In Indonesia, disputes regarding the naming of black rice cultivars need to be resolved. The diversity of black rice cultivars results partly from their genetic variability, which in turn gives rise to differences in their phytochemical composition. Consequently, it is important to understand these varieties and their respective nutritional and health-related benefits in working toward developing functional foods based on black rice-associated materials and compounds. To date, there have been several studies on local black rice cultivars focusing on genetics analysis based on morphological characters, geographic distribution, anthocyanin and antioxidant components, and other phytochemical analyses. However, only a few studies focus on the nutraceutical value of black rice. Therefore, significantly more research is required in working toward the development of black rice as a functional food.

Competing interests: The authors have no financial interests or any other conflicts of interest to disclose

Authors' contributions: RP was collected the references and wrote the content of review; YAP was involved in adding the information of black rice production

Acknowledgments and Funding: We thank Dr. Richard Luke Daniels (Department of Biology, The College of Idaho, USA) for valuable comments on the manuscript. This work was supported by The Ministry of Research, Technology and Higher Education of Republic of Indonesia under the National Research Competitive Projects 2015-2016.

\section{REFERENCES}

1. Thomson MJ, Septiningsih EM, Suwardjo F, Santoso TJ and SilitongaTS: Genetic diversity analysis of traditional and improved Indonesian rice (Oryza sativa L.)germplasm using microsatellite markers. Theor Appl Genet 2007, 114:559-568.

2. Chen Q, Nagao N, Itani T, and Irifune K: Anti-oxidative analysis, and identification and quantification of anthocyanin pigments in different colored rice. Food Chemistry 2012, 135: 2783-2788.

3. Kristamtini, Taryono, Basunanda P, Murti RH, Supriyanta, Widyayanti S and Sutarno: Morphological of genetic relationships among black rice landraces from Yogyakarta and surrounding areas. ARPN Journal of Agricultural \& Biological Science 2012, 7(12): 982989.

4. Rai M: Genetic diversity in rice production: past contribution and the potential of utilization for sustainable rice production. In Proceedings of the 20th Session of the International Rice Commission: Sustainable rice production for food security, Produced by Agriculture and Consumer Protection Bangkok, Thailand 23-26 July 2002. FAO. Part III. 2003.

5. Rao SA, Schiller JM, Bounphanousay C, Inthapanya P, and Jackson MT: The colored pericarp (black) Rice of Laos: Rice in Laos edited by J.M. Schiller, M.B. Chanphengxay, B. Linquist, and S. Appa Rao, Los Baños (Philippines): International Rice Research Institute, 2006: 175-187. 
6. Le MT and Yang Y: Morphological characterization and phytochemical analysis of pigmented rice cultivars from diverse regions "Breeding, Genetics, and Physiology" in AAES 2005, Research Series 540: 77-86.

7. Lee JH. Identification and quantification of anthocyanins from the grains of black rice (Oryza sativa L.) varieties. Food Sci. Biotechnol 2010, 19(2): 391-397

8. Kang MY, Kim JH, Rico CW and Nam SH. A Comparative study on the physicochemical characteristics of black rice varieties. International Journal iof Food Properties 2011, 14: 1241-1254.

9. Yodmanee S, Karla TT and Pakdeechanuan P: Physical, chemical, and antioxidant properties of pigmented rice grown in Southern Thailand. International Food Research Journal 2011, 18(3): 901-906

10. Oikawa T, Maeda H, Oguchi T, Yamaguchi T, Tanabe N, Ebana K, Yano M, Ebitani T, and Izawa T: The birth of a black rice gene and its local spread by introgression. Plant Cell 2015, 27(9): 2401-14.

11. Kushwaha UKS: Black Rice: Research, History, and Development. Springer, 2016: 21-47.

12. Sompong R, Ehn SS, Martin GL, Berghofer E: Physicochemical and antioxidative properties of red and black rice varieties from Thailand, China and Sri Lanka. Food Chemistry 2011, 124: 132-140.

13. Kang MY, Kim JH, Rico CW and Nam SH: A comparative study on the physicochemical characteristics of black rice varieties international. Journal of Food Properties 2011, 14: 1241-1254.

14. Pengkumsri N, Chaiyasut C, Saenjum C, Sirilun S, Peerajan S, Suwannalert P, Sirisattha $\mathrm{S}$, and Sivamaruthi BS: Physicochemical and antioxidative properties of black, brown and red rice varieties of Northern Thailand. Food Sci. Technol Campinas 2015, 35(2): 331338.

15. Sa'adah IR, Supriyanta, and Subejo: Diversity of grain color and rice color of local variety of black rice (Oryza sativa L.) that cultivated by the farmer in Sleman, Bantuland Magelang regencies. Vegetalika 2013, 2(3): 13-20.

16. Kristamtini, Taryono, Basunanda P dan Murti RH: Genetic variability of rice pericarp color parameters and total anthocyanin content of eleven local black rice and their correlation. Ilmu Pertanian 2014, 17 (1): 90 - 103.

17. Murdifin M, Pakki E, Rahim A, Syaiful SA, Ismail, Evary YM and Bahar MA: Physicochemical properties of Indonesian pigmented Rice (Oryza sativa Linn.) varieties from South Sulawesi. Asian J Plant Sci 2015, 14(2): 59-65.

18. Budiman, Arisoesilaningsih E and Wibowo RBE: Growth adaptation of two Indonesian black rice origin NTT cultivating in the organic paddy field, Malang-East Java. J Trop Life Science 2012, 2(3): 77 - 80.

19. Suhartini T dan Suardi D: Potensi beras hitam lokal Indonesia. Warta Penelitian dan Pengembangan Pertanian 2010, 32(1): 9-10

20. Lestari P, Utami DW, Rosdianti I and Sabran M: Morphological variability of Indonesian rice germplasm and the associated SNP markers. J Food Agric 2016, 28(9): 660-670.

21. Park, Sam Y, Kim SJ, and Chang HI: Isolation of anthocyanin from black rice (Heugjinjubyeo) and screening of its antioxidant activities. Kor J Microbiol Biotechnol 2008, 36 (1): 55-60.

22. Zhang MW, Zhang RF, Zhang FX, and Liu RH: Phenolic profiles and antioxidant activity of black rice bran of different commercially available varieties. J Agric Food Chem 2010, 58: 7580-7587. 
23. Sriseadka T, Wongpornchai S and Rayanakorn M: Quantification of flavonoids in black rice by liquid chromatography-negative electrospray ionization tandem mass spectrometry. J Agric Food Chem 2012, 60:1723-11732.

24. Goufo P and Trindade H. Rice antioxidants: phenolic acids, flavonoids, anthocyanins, proanthocyanidins, tocopherols, tocotrienols, c-oryzanol, and phytic acid. Food Science \& Nutrition 2014: 2(2): 75-104.

25. Jun HI, Shin JW, Song GS, and Kim YS: Isolation and identification of phenolic antioxidants in black rice bran. Journal of Food Science 2015, 80(2): 262-268.

26. Kaneda I, Kubo F, and Sakurai J: Isolation and Identification of Phenolic Antioxidants in Black Rice Bran. J Health Sci 2006, 52: 495- 511.

27. Ichikawa H, Ichiyanagi T, Xu B, Yoshii Y, Nakajima M, and Konishi T: Antioxidant activity of anthocyanin extract from purple-black rice. Journal of Medicinal Food 2004, 4(4): 211-218.

28. Kim GR, Jung ES, Lee S, Lim SH, Ha SH, and Lee CH: Combined mass spectrometrybased metabolite profiling of different pigmented rice (Oryza sativa L.) seeds and correlation with antioxidant activities. Molecules 2014, 19: 15673-15686.

29. Nam SH, Choi SP, Kang MY, Koh KJ, Kozukue N and Friedman M: Antioxidative activities of bran extracts from twenty one pigmented rice cultivars. Food Chemistry 2006, 94: 613-620.

30. Moko EM, Purnomo H, Kusnadi J, and Ijong FG: Phytochemical content and antioxidant properties of colored and non colored varieties of rice bran from Minahasa, North Sulawesi, Indonesia. IFRJ 2014, 21(3): 1053-1059.

31. Xia M, Ling WH, Ma J, Kitts DD and Zawistowski J: Supplementation of diets with the black rice pigment fraction attenuates atherosclerotic plaque formation in apolipoprotein $\mathrm{E}$ deficient mice. J Nutr 2003, 133(3): 744-751.

32. Um MY, Ahn J and Ha TY: Hypolipidaemic effects of cyanidin 3-glucoside rich extract from black rice through regulating hepatic lipogenic enzyme activities. J Sci Food Agric 2013, 93: 3126-3128.

33. Guo H, Ling W, Wang Q, Liu CI, Hu Y, Xia M, Feng X and Xia X: Effect of Anthocyaninrich extract from black rice (Oryza sativa L. indica) on hyperlipidemia and insulin resistance in fructose-fed rats. Plant Foods for Human Nutrition 2007, 62: 1-6

34. Yoshida H, Tomiyama (Sakamoto) Y, Mizushina Y and Yoshida N: Profiles of Fatty Acid Distribution of Different Acyl Lipids from Red and Black Rices. Journal of Food Research 2012, 1(3): 46-53.

35. Ling WH, Cheng QX, Ma J and Wang T: Red and black rice decrease atherosclerotic plaque formation and increase antioxidant status in rabbits. J Nutr 2001, 131: 1421-1426.

36. Zawistowski J, Kopec A, and Kitts DD: Effects of a black rice extract (Oryza sativa L. indica) on cholesterol levels and plasma lipid parameters in Wistar Kyoto rats. Journal of Functional Foods 2009, 1: 50-56

37. Jang HH, Park MY, Kim HW, Lee YM, Hwang KA, Park JH, Park DS and Kwon O: Black rice (Oryza sativa L.) extract attenuates hepatic steatosis in C57BL/6 J mice fed a high-fat diet via fatty acid oxidation. Nutrition \& Metabolism 2012, 9(27): 1-11.

38. Zhang X, Shen Y, Prinyawiwatkul W, King JM, Xu Z: Comparison of the activities of hydrophilic anthocyanins and lipophilic tocols in black rice bran against lipid oxidation. Food Chemistry 2013, 141: 111-116.

39. Kim SY, Kim YJ, An YJ, Lee HJ, Lee SH, Kim JB, Kim HR and Lee SJ: Black rice (Oryza sativa, Heukmi) extracts stimulate osteogenesis but inhibit adipogenesis in mesenchymal c3h10t1/2 cells. Journal of Food Biochemistry 2016, 40: 235-247. 
40. Pratiwi R, Purwestri YA, and Tunjung WAS: Effect of Diet Rice Pellets (Oryza sativa L.) 'Cempo Ireng', 'Cempo Abang', and 'IR-64' to Lipid Serum Profile of White Rat (Rattus norvegicus Berkenhout, 1769) Hyperlipidemia. Proceeding of Seminar and Workshop on Nutrigenomic, Yogyakarta March 2013; Indonesia 2014: 12-18.

41. Wahyuni AS, Munawaroh R, and Da'i M: Antidiabetic mechanism of ethanol extract of black rice bran on diabetic rats. National Journal of Physiology, Pharmacy, and Pharmacology 2016, 6 (2): 106-110.

42. American Cancer Society: Cancer Facts \& Figures 2013. Atlanta: American Cancer Society, 2013

43. American Cancer Society: Cancer Facts \& Figures 2016. Atlanta: American Cancer Society, 2016.

44. Iriti M, and Varoni EM: Chemopreventive potential of flavonoids in oral squamous cell carcinoma in human studies. Nutrients 2013, 5: 2564-2576.

45. Hudson EA, Dinh PA, Kokubun T, Simmonds MSJ, and Gescher A: Characterization of potentially chemopreventive phenols in extracts of brown rice that inhibit the growth of human breast and colon cancer cells. Cancer Epidemiology, Biomarkers \& Prevention 2000, 9: 1163-1170.

46. Chen PN, Chu SC, ChioL CL, Yang SF, and Hsieh YS: Cyanidin 3-glucoside and Peonidin 3 -glucoside inhibit tumor cell growth and induce apoptosis in vitro and suppress tumor growth in vivo. Nutrition and Cancer 2005, 53(2): 232-243.

47. Leardkamolkarn V, Thongthep W, Suttiarporn P, Kongkachuichai R, Wongpornchai S, and Wanavijitr A, Chemopreventive properties of the bran extracted from a newly-developed Thai rice: The Riceberry. Food Chemistry, 2011; 125: 978-985.

48. Banjerdpongchai R, Wudtiwai B, and Sringarm K: The cytotoxic effect of purple rice extracts on human cancer cells related to their active compounds. Proceeding of 13th ASEAN Food Conference, Singapore, 2013; 1-10.

49. Takashima A, Ohtomo M, Kikuchi T, Iwashita J, Abe T, and Hata K: Differentiation- and apoptosis-inducing activities of rice bran extracts in a human colon cancer cell line. J Food Sci Technol 2013, 50(3): 595-599.

50. Chen PN, Kuo WH, Chiang CL, Chiou HL, Hsieh YS, and Chuc SC: Black rice anthocyanins inhibit cancer cells invasion via repressions of MMPs and u-PA expression. Chemico-Biological Interactions 2006, 163: 218-229.

51. Pratiwi R, Tunjung WAS, Rumiyati and Amalia AR: Apoptosis induction in humancervical cancer cells by pigmented rice bran fractions containing cyanidin 3glucoside and peonidin 3-glucoside. Indonesian Journal of Biotechnology 2015, 20(1): 1926.

52. Varela SL, Gross and Marcos A: Functional foods and the immune system: a review. European Journal of Clinical Nutrition 2002, 56(3): S29-S33.

53. Purwestri YA, Sari RDK, Anggraeni LN, Sasongko AB: Agrobacterium tumefaciens mediated transformation of rolC::Hd3a-GFP in black rice (Oryza sativa L. cv. Cempo Ireng) to promote early flowering. Procedia Chemistry 2015, 14: $469-473$.

54. Purwestri YA, Susanto FA, and Fauzia AN: The preliminary study of enhancing black rice as functional food: expression pattern of flowering genes in long harvest black rice cultivar Cempo Ireng. Proceedings of Pakistan Academy Sciences, in press.

55. Black Rice and Organic Farming, fortunately Larger.

[http://wartawirausaha.com/2014/08/bertani-beras-hitam-dan-organik-untungnya-lebih-Besar]

56. Friedman M: Rice brans, rice bran oils, and rice hulls: composition, food and industrial uses, and bioactivities in humans, animals, and cells. J Agric Food Chem 2013, 61:10626-10641. 
57. Kang MY, Kim JH, Rico1 CW, and Nam SH: A Comparative study on the physicochemical characteristics of black rice varieties. International Journal of Food Properties 2011, $14: 1241-1254$.

58. Pereira-caro GS, Watanabe A, Crozier T, Fujimura T, Yokota H, and Ashihara. Phytochemical profile of Japanese black-purple rice. Journal of Food Chemistry, 2013: 28212827.

59. Shipp J and Abdel-Aal ESM: Food applications and physiological effects of anthocyanins as functional food ingredients. The Open Food Science Journal 2010, 4: 7-22.

60. Yawadio R and Morita N: Color enhancing effect of carboxylic acids on anthocyanins. Food Chemistry 2007, 105: 421-427.

61. Obón JM, Castellar MR, Alacid M, and Fernández-López JA: Production of a red-purple food colorant from Opuntia stricta fruits by spray drying and its application in food model systems. Journal of Food Engineering 2009, 90: 471-479.

62. Megan E. West and Lisa J. Mauer. Color and chemical stability of a variety of anthocyanins and ascorbic acid in solution and powder forms. J. Agric. Food Chem., 2013; 61(17): 41694179.

63. Jati IRAP, Nohr D. and Biesalski HK: Nutrients and antioxidant properties of Indonesian underutilized colored rice. Nutrition \& Food Science 2014, 44(3): 193-203.

64. Sui X, Yap PY and Zhou W: Anthocyanins During Baking: Their Degradation Kinetics and Impacts on Color and Antioxidant Capacity of Bread. Food and Bioprocess Technology 2015, 8(5): 983-994.

65. Sui X, Zhang Y, and Zhou W: Bread fortified with anthocyanin-rich extract from black rice as nutraceutical sources: Its quality attributes and in vitro digestibility. Food Chemistry 2016, 196: 910-916. 